\title{
The Interactions between Cosmopolitanization and Migration: New Trends
}

\author{
Larysa Sarakun, Larysa Babushka, Vasily Drapohuz, Oksana Popova
}

\begin{abstract}
The author made a philosophical analysis of the migration phenomenon. The problems of cosmopolitanization and migration in the context of globalization have been observed and their main vectors of interaction have been pointed out here. The new methodology is cosmopolitanization. It means the world experience and cultural infinity. Global interdependence and risks of available knowledge change social and political quality of national communities. This feature is defined as cosmopolitanization. The cosmopolitan idea spreading is related to migration mainstreaming, integration and globalization. Therefore there is a need to study interference issues of cosmopolitanization and migration, the prospects of their development in the context of globalized modernity.

The migration analysis can detect the general conditions of its occurrence. It helps to consider the migration structure and make a comparative analysis of immigration forms, to establish this role in the society. The philosophical understanding of the migration phenomenon is reflected in a number of concepts, including concepts of passionary changes.

The migration system in the world is characterized by close economic, cultural, political and geographical bonds. The phenomenon is associated with the term "globalization" in the context of current international relations. Nowadays migration intensifies and moves into a new stage. An essential part of immigration policy is a policy of integration of migrants, which involves targeted measures in many areas of society.

In this article the author reveals interaction principles of migration and cosmopolitanization. This means that a closed society disappears forever. However, most people do not perceive it as liberation. As it was noted by Ulrich Beck, the rejection of the national paradigm is not tantamount to a global «cosmopolitanism of common good».

Cosmopolitanization is a response to a changing world. How will the humanity evolve? Will migration processes, integration, interaction and people interdependence develop? Will resistance to globalization be intensified? What will be the attractor of social development?
\end{abstract}

Keywords: $\quad$ cosmopolitanism; globalization; cosmopolitanization; migration; migration process; migration policy.

Revised Manuscript Received on December 30, 2019.

* Correspondence Author

Larysa Sarakun, Ph. D., Associate Professor, Department of Humanities, National University of Food Technology (Kyiv, Ukraine)

68 Volodymyrska str., 01601 Kyiv, Ukraine, E-mail: sarakyn@rambler.ru, https://orcid.org/0000-0002-4692-2145

Larysa Babushka, Ph. D., Associate Professor, Chair of Theory and History of Culture of the National Music Academy of Ukraine named after Peter Tchaikovsky (Kyiv, Ukraine) Philosophy, Center for Humanitarian Education of NAS of Ukraine (Kyiv, Ukraine)

Oksana Popova, Ph. D., Associate Professor, Social Sciences and Humanities Department, National University of Physical Education and Sports of Ukraine (Kyiv, Ukraine)

(c) The Authors. Published by Blue Eyes Intelligence Engineering and Sciences Publication (BEIESP). This is an open access article under the CC BY-NC-ND license (http://creativecommons.org/licenses/by-nc-nd/4.0/)
Vasily Drapohuz, Ph. D., Associate Professor, Department of

\section{INTRODUCTION}

The important problems of the worldview individual adaptation and temporary migration to another cultural space are becoming increasingly in the globalization context and accelerating migration process. Nowadays the ground problem of conceptualizing cultural specificity for human existence in the modern world is cosmopolitanism and migration processes which are considered in this interaction. The mentioned phenomena are unconsciously present in different areas and at various levels of our society. Cosmopolitan and migration conceptualizing as interrelated and complementary phenomena of life allow rethink problems and prospects of preservation and cultural diversity development in a globalized world for optimizing intercultural communication.

\section{LITERATURE REVIEW}

Analysis of recent research and publications on selected issues indicates that philosophical and methodological consideration of the problem is conducted by foreign researchers D. Archibugi, K. Appia, 3. Bauman, W. Beck, I. Wallerstein, M. Hibernau, E. Giddens, M. Papastepanow, D. Held. They consider the phenomenon of cosmopolitanism in the context of the construction of a new paradigm of awareness of the world order and the necessary step of humanity for the further existence. However, the question of the interaction of cosmopolitanism and migration is not raised. The aim of this work is to study the basic vectors of cosmopolitanization and migration interaction.

\section{MATERIALS AND METHODS}

In accordance with specific tasks at various stages of the study such methodological approaches and methods as systemic-structural, comparative, structural-functional, comparatively-historical, hermeneutical, analogies, structural-logical modeling, interpretations are used. The dialectical method and the systematic approach are also used.

\section{RESULTS AND DISCUSSIONS}

The Ukrainian scientist V. Zubov describes the current state of the international community as turbulent one. The term «turbulence» denotes the occurring random and unforeseen effects, which causes the financial system slacking, loss of control and stability over the situation, the system destruction. This is due to the global crisis in the whole system processes and «reformatting» global architectonics can lead to geopolitical conflicts and world powers confrontation (6, p. 66). 
Crisis in the modern society development can lead to the intensification of migration processes that change the population outlook. Migrants contribute cosmopolitanization. According to the UN, today in the world there are about 232 million international migrants (3\% of the world population) and about a billion of domestic workers (11, p. 3). Their presence creates a challenge always and everywhere to have a clear distinction between «us» and «them», «friends» and «foes», «citizens» and «outsiders». The host country reinforces this necessity for implants. Migrants embody all possible gradations of both sides. These are foreigners or foreign nationals whose social skills are not only constant, but also enrich the cultural and social life. Their situation is functional, legitimate and illegal at the same time, it «is allowed, but not recognized» (1, p. 155). The existence of migrants, their activities and attempts to enter the public arena contradict the understanding of civil rights in the national state and at the same time give them a different meaning.

Specificity of the national cosmopolitan society comes from extending the ethnic solidarity so as to allow the participation of both domestic and external outsiders. Involvement in post sovereign public order involves willingness, focus and the ability to participate in it, as well as some self-organization. Only in this way «natives» and «foreigners» will cooperate in the cosmopolitan spaces as equal members of transnational civil society.

Another Ukrainian researcher A. Soshnikov points that cosmopolitanism became the signature of «reflexive modern age», which eliminated state borders and national differences. This global changes demand new research methodology (instead of «national», which means the basic categories and national sovereignty) (14).

The new methodology is cosmopolitanism. It is experience the world in general and cultural infinity. Ulrich Beck calls this point of view «methodological cosmopolitanism». Considering the causes of cosmopolitan society, it seeks to identify the root causes of such transformation nationally organized societies: «Global interdependence and risks of available knowledge and changing of social and political quality of national communities. It is the main feature of cosmopolitanization. It is internal, that is, one that stems from within national communities or local cultures, it is also self - is always distorted - and there in the national consciousness. Just change the basics of everyday consciousness and identity. Topics that are of global importance become an integral part of everyday experience and «moral life world». They question the national identity form that lead to major conflicts in the world» $(15$, p. 113). As methodology of knowledge correlates with cosmopolitanism, U. Beck proposes the concept of «methodological cosmopolitanism». The idea, in his opinion, brings together in one unit cognitive social reality, interpretation of everyday items and scientific observation and in addition allows «self-critical sociology combination of methodological cosmopolitanism that would be a breakthrough in the social science» $(15$, p. 117).

Summing up of its previous dynamic socio-political, economic and cultural development, mankind finds that the unprecedented scale of national, ethnic and regional movements (often uncompromising) appears in clear contradiction with international communication and economic trends of global integration. The human universals impact has been increased. At the same time, despite of the ethnic culture weakening, we can say the growth of ethnic identity and strengthen the sense of ethnicity. The theme of interethnic communication is a priority in the world (global) and the national (local) dimensions. Note that ethnic consciousness often becomes hypertrophied forms (national extremist, anti-Semitic, racist, xenophobic and chauvinistic) that affect the processes of intercultural communication. Analyzing modern scientific and philosophical vision of the ethnic dimension of the global world, A. Soshnikov notes that the global system will not fight and live with politicized ethnicity in a variety of forms in the near future. Providing such coexistence requires a fundamentally new paradigm for practical solution of national problems than the one used now. Today we see the opposite effect but objectively interrelated trends. On the one hand, the deepening of the integration process, striving to overcome multiculturalism and multiculturalism of modern societies through their unification naturally requires a reduction of national importance to the socio-cultural universal for success. This is a contemporary globalization feature. On the other hand, the society, despite of the global impact of modernization, becomes more ethicized. The presence of ethnicity manifests everywhere, in some areas of public life, has a dominant influence. In this sense the present century can be characterized not only by cosmopolitanism, but nationalism, which acts as a specific response to the global unification of the world (14).

Cosmopolitanism distribution means that a closed society disappears. However, most people do not perceive it as liberation. On the contrary, they believe in the crash of «their world». They are very difficult to manage to navigate the maze of closed society, based on the opposition of «we» and «others», internal and external, national and international. Now they are suddenly faced with the contradictions and tolerant social form of freedom, which is not easy to understand and experience and which reduce them to a state of strangers in their own land (1, p. 163). The term «foreign» becomes a comprehensive power as a person is faced with challenges and contradictions that make it to the stranger. Hatred of foreigners lights by existential fears. Therefore people feel themselves disoriented, alienated and unnecessary in a tolerant society through excessive freedom. As the German scientist U. Beck considers, the rejection of the national paradigm is not tantamount to a global «cosmopolitanism of common good» as it is formulated various directions of civil society. But we cannot exclude that the national neoliberalism «abandonment of solidarity» (globalism) would deploy in cosmopolitan direction. This can happen if the context of the global division of labor and wealth to replace solidarity with relatives or fellow citizens into with foreigners solidarity. According to the scientist it is possible to determine the number of different scenarios. One of them is a global migration. Migration processes of the future will be characterized by conflict between two «age pyramids». Today aging Western countries are opposed by youth community of peripheral countries. It raises, firstly, the immigration pressure from outside, secondly, the internal pressure that forces immigrants to accept; anyway, the migration will be a key political topic, it will depend on the survival open world in Europe (1, p. 162). 
These trends pointed by U. Beck we see today. Migration policy of the European Union now has become one of the critical problems in European countries, along with internal, economic crisis, unemployment and insecurity. At the informal summit in Bratislava (September 2016) the leaders of 27 countries (EU members) agreed to submit a detailed plan of the European Union Development (including exit of The United Kingdom) in six months. According to the German Chancellor Angela Merkel, special attention should be paid to the issue of curbing illegal migration and strengthening cooperation on security. At the summit, the European Council President Donald Tusk said that one of the main objectives of EU leaders was to prevent the uncontrolled flow of migrants, which had been observed last year. At the same time, the Hungarian Prime Minister Viktor Orban said that the informal summit participants failed to amend the EU's migration policy, which he called «naive and self-destructive» (10).

There are a lot of theories of migration today. The migration analysis can detect the general conditions of their occurrence, consider the structure of migration and make a comparative analysis of immigration forms. Today, migration is a subject of study of various sciences such as History, Sociology, Philosophy, Conflictology, Demography, Economics, Law and others.

The researcher of migration A. Kuzmin distinguishes seven basic approaches to its study. There are demographic, sociological, historical, legal, psychological, philosophical and economic ones (9). But another scientist V. Iontsev offers near seventeen approaches, including the systematic, geographic, genetic, biological, ethnographic aspects (7).

Philosophy, for example, uses a comparative approach in migration studying and can abstract from the existing «qualifying» characteristics of the concept and give its wide interpretation (the movement of people in space). Based on this concept, we can examine the source and incoming flows of migration on a global scale, to explain the behavior of individuals or social groups, motivated by different reasons. The philosophical understanding of the migration phenomenon is reflected in a number of concepts, including concepts of passionary changes (by L.Gumilev), which is based on the idea of energy exchange between the human community (ethnic groups) and the environment. The surplus of biochemical energy of living matter creates the effect passionarity aimed at changing ethnic group as well as to changes in the environment. Passionarity determines migration of the entire nation. Its global changes explain many historical events.

Migratory movements should be seen in different contexts and reveal their impact not only on the demographic characteristics of a territory, but also the economic and cultural indicators of social development, social structure, that show the relationship of social and migration processes that may be under the influence various factors and reasons. In recent years, migration flows acquire a large scale, which leads to the emergence of relatively stable incoming and outgoing flows of these points. The mentioned items are specific countries that are exporters or importers in accordance migrants. This is the basis for setting immigration system that is due at least two participating countries for migration exchange. Thus, the migration system that unites France with the countries of North Africa is one of the world's migration system centered in Europe.
We note that in the second half of the last century Western and Northern parts of Europe, then Southern one, and in the early 2000s, Central and Eastern Europe experienced a socalled migration transition. It was the transformation of the territory where the population is eliminated, with following numerous immigration flows. This was the root cause of migration management systems of European countries initially at national and then at regional level (11, p.4).

The migration system in the world today is characterized by close economic, cultural, political, geographic links between countries. It allows determining migration as a single system. It is characterized by the diversity of migratory flows, their various types, the emergence of new EU immigration and entry of new countries of origin of migrants form a new vector migration «East - West», which recently replaced the dominant vector «South - North». This phenomena is associated with the term «globalization» in the context of current international relations and migration problems have deteriorated and moved into a new stage. Former intergovernmental contacts evolved into a full legislative power community, a significant part of the acquis communautaire. This is due to the objective need to develop common approaches to regulation of migration as a result of the intensification inside and outside the community, and in the context of deepening European integration. (11, p. 44). Also migration has economic benefits. Firstly, it changes the demographics and provides up to $40 \%$ of the population growth, particularly in Europe. Especially welcome is the arrival of highly skilled migrants and their contribution to the economy formation, which is based on knowledge. Secondly, it impacts on investment needs (housing and other infrastructure), particularly in densely populated countries. Although the influx of people from other countries to European societies is not only the benefits but also problems, it provides effective regulation for sustainable development. Migrants bring diversity and cultural dynamics. Subsequently, a large-scale migration transforms the host country culture. It affects the dominant values of the state. People have different opinions on the correct migration policy. Some countries are either «closed» or completely «open». To find a balance is difficult. During this search is reasonable for states to claim that the key for them will always be their own citizens. At the same time, as the Nobel laureate Thomas Schelling points, it may be significant segregation. People in this case will live separately from each other and that they had to unite.

An essential part of immigration policy is a policy of integration of migrants. After all, the success or failure of integration measures depends on the final result of migration, which may facilitate the development of the country of destination, but at the same time carries risks of violations of homogeneity of society until conflict situations. It is clear that integration occurs at the local level, because the issues involved are naturally the responsibility of individual countries. It is important to the understanding of integration as a «two-way process» that is based on mutual rights and obligations of citizens of other countries who are legally staying in the communities that host them (11, p. 30). 
Policy integration involves targeted measures with the migration, but also in other spheres of society, especially in the labor market, to ensure migrants access to education, health, social services, their active participation in cultural and political life of the host country. Special attention should be paid to specific groups of migrants, including young people, women and refugees. However, the efforts of governments should be directed also to society as a whole to ensure its readiness for acceptance of migrants, cultural and linguistic diversity, forming a new identity.

Many modern humanitarians agree that the prospects of the global community are unclear. Along with a number of possible partly competing and partly complementary perspectives, U. Beck considers the prospects of the international community as such, are based not only on experience of similarly comprehension in the civil society, but also on the transnational significance of fundamental rights (2, p. 163). Explaining this situation, it notes that «the essence is differentiation of human subjects of different states, and thus ultimately guarantees the rights of citizenship for the entire world» (2, p. 163-164). Thus U. Beck notes the paradox situation, which is subject to the simultaneous presence of the national state of human rights and global citizenship, which implies a guarantee cosmopolitan relations. In building relationships between participants embodiment of the prospect of the global community it provides for the implementation of three models: real-political, internationalist and cosmopolitan. National and state judiciary is a main role in the first two models. The cosmopolitan model presents the individual whose rights have been supported by the United Nations. The author of the idea of "cosmopolitan democracy» notes the many unresolved issues that arise during its implementation capabilities, and expresses only hope for its realization.

\section{CONCLUSIONS}

So, cosmopolitanism is the possibility of forming a new environment with a new identity, a response to the changing world. We do not know, how our humanity will develop. Will migration processes, integration, interaction and people interdependence develop? Will resistance to globalization be intensified? What will be the attractor of social development? So this phenomenon requires a new paradigm of thinking.

\section{LITERATURE}

1. Бек У. Космополитическое мировоззрение / Ульрих Бек. - М.: Центр исследований постиндустриального общества, 2008. - 336 с.

2. Бек У. Что такое глобализация? Ошибки глобализма - ответы на глобализацию / Ульрих Бек. - М., 2001. - 237 с.

3. Бреева Е. Б. Основы демографии / Е. Б. Бреева. М.: Дашков и К, 2014. - 352 с.

4. Гусев К. Любовь по-новофранцузски и вселенская миграция. Что делать? / К.Гусев // http://www.centrasia.ru/newsA.php?st=1451024160.

5. Дианова В.M. Космополитизм в эпоху глобализации / В.М. Дианова // Вопросы культурологи. - 2007. - № 1. - С. 8-12.

6. Зубов В.О. Соціальна турбулентність як підгрунтя змін у світоглядних настановах сучасної людини /
В.О. Зубов, Л.Д. Кривега // Актуальні проблеми філософії та соціології. - № 8, 2015. - С. 66-68.

7. Ионцев В. А. Международные миграции населения / МГУ им. М.В. Ломоносова / В.А. Ионцев. - М.: Диалог, 2009. - 244 с.

8. Кузнецов А.М. Глобализация или космополитизация: об одном дискурсе современной западноевропейской социологии / А.М. Кузнецов // СОЦИС, 2014. - № 12. - С. 12-20.

9. Кузьмин А.И. Курс лекций «Основы демографии» [Электронный ресурс] / А.И. Кузьмин - режим доступа: http:/humanities/edu.ru/db/msg/47066/ Загл. с экрана.

10. Лідери ЄС домовилися представити новий план розвитку Союзу // ВВС. - [Електронний ресурс]. режим доступа: http://www.bbc.com/ukrainian/politics/2016/09/16091 7_eu_bratislava_declaration_sx.

11. Малиновська О.А. Міграційна політика Європейського союзу: виклики та уроки для України / О. А. Малиновська. - К.: НІСД, 2014. 48c.

12. Назик Ж. Миграционные процессы как стимул и тормоз социально-экономического развития, как страны-реципиента, так и страны-донора / Ж. Назик // Сборник лекций молодых ученых. M., 2014. - С. $9-28$.

13. Рыбаковский Л.Л. Миграция населения. Три стадии миграционного процесса (очерки теории и методов исследования) [Электронный ресурс] / Л.Л. Рыбаковский - режим доступа: http: / 7www.viperson.ru/wind.php/ID=250095\&soch=1. Загл. с экрана. - C.106-107.

14. Сошников А.А. «Методологический национализм» и «методологический космополітизм»: концептуализация национальных реалий в теоретических версиях глобального общества / А.А. Сошников // Електронный ресурс - режим доступа: http://teoriapractica.ru/rus/files/arhiv_zhurnala/2013/9/fil\%D0\%B Es\%D0\%BEfiy\%D0\%B0/soshnikov.pdf

15. Beck U. Der kosmopolitische Blick oder: Krieg ist Frieden. Frankfurt am Main, 2004.

\section{REFERENCES}

1. Bek U. Kosmopolytycheskoe myrovozzrenye / Ul'rykh Bek. - M. Tsentr yssledovanyy postyndustryal'noho obshchestva, 2008. - $336 \mathrm{~s}$.

2. Bek U. Chto takoe hlobalyzatsyya? Oshybky hlobalyzma - otvetы na hlobalyzatsyyu / Ul'rykh Bek. - M., 2001. - 237 s.

3. Breeva E. B. Osnovы demohrafyy / E. B. Breeva. - M.: Dashkov y K, 2014. $-352 \mathrm{~s}$.

4. Husev K. Lyubov' po-novofrantsuzsky y vselenskaya myhratsyya. Chto delat'? / K.Husev http://www.centrasia.ru/newsA.php?st=1451024160.

5. Dyanova V.M. Kosmopolytyzm v эpokhu hlobalyzatsyy V.M. Dyanova // Voprosы kul'turolohy. - 2007. - № 1. - S. 8-12.

6. Zubov V.O. Sotsial'na turbulentnist' yak pidgruntya zmin u svitohlyadnykh nastanovakh suchasnoyi lyudyny / V.O. Zubov, L.D. Kryveha // Aktual'ni problemy filosofiyi ta sotsiolohiyi. - № 8, 2015 - S. $66-68$.

7. Yontsev V. A. Mezhdunarodnыe myhratsyy naselenyya / MHU ym. M.V. Lomonosova / V.A. Yontsev. - M.: Dyaloh, 2009. - 244 s.

8. Kuznetsov A.M. Hlobalyzatsyya yly kosmopolytyzatsyya: ob odnom dyskurse sovremennoy zapadnoevropeyskoy sotsyolohyy / A.M. Kuznetsov // SOTsYS, 2014. № 12. - S. 12-20. 
9. Kuz'myn A.Y. Kurs lektsyy «Osnovы demohrafyy» [Эlektronnыy resurs] / A.Y. Kuz'myn - rezhym dostupa: http:/humanities/edu.ru/db/msg/47066/ - Zahl. s эkrana.

10. Lidery YeS domovylysya predstavyty novyy plan rozvytku Soyuzu // VVS. - [Elektronnyy resurs]. - rezhym dostupa: http://www.bbc.com/ukrainian/politics/2016/09/160917_eu_bratislava _declaration_sx.

11. Malynovs'ka O.A. Mihratsiyna polityka Yevropeys'koho soyuzu: vyklyky ta uroky dlya Ukrayiny / O. A. Malynovs'ka. - K.: NISD, 2014. $-48 \mathrm{~s}$

12. Nazyk Zh. Myhratsyonnыe protsessы kak stymul y tormoz sotsyal'noэkonomycheskoho razvytyya, kak stranы-retsypyenta, tak y stranыdonora / Zh. Nazyk // Sbornyk lektsyy molodukh uchenыkh. - M., 2014. - S. 9-28.

13. Rubakovskyy L.L. Myhratsyya naselenyya. Try stadyy myhratsyonnoho protsessa (ocherky teoryy y metodov yssledovanyya) [Эlektronnыy resurs] / L.L. Rыbakovskyy - rezhym dostupa: http: / 7www.viperson.ru/wind.php/ID=250095\&soch=1. Zahl. s эkrana.-S.106-107.

14. Soshnykov A.A. «Metodolohycheskyy natsyonalyzm» y «metodolohycheskyy kosmopolityzm»: kontseptualyzatsyya natsyonal'nukh realyy $\mathrm{v}$ teoretycheskykh versyyakh hlobal'noho obshchestva / A.A. Soshnykov // Elektronniy resurs - rezhym dostupa: http://teoriapractica.ru/rus/files/arhiv_zhurnala/2013/9/fil\%D0\%BEs\%D0\%BEfiy $\% \mathrm{D} 0 \% \mathrm{~B} 0 /$ soshnikov.pdf

15. Beck U. Der kosmopolitische Blick oder: Krieg ist Frieden. Frankfurt am Main, 2004. 